\title{
An Aspect of Colonialism and Anti-Colonialism: A Comparative Study between the Traces of British Imperialism in English Literature and the Counterpoint of Anti-Colonialism in Bengali Literature of 19th Century
}

\author{
Farhana Haque (Corresponding author) \\ Department of English and Humanities, Faculty of Arts and Humanities, Brac University, Mohakhali, Dhaka, Bangladesh \\ E-mail: dhak_121@yahoo.com
}

Doi:10.7575/aiac.alls.v.7n.5p.85

Received: 20/05/2016

URL: http://dx.doi.org/10.7575/aiac.alls.v.7n.5p.85

Accepted: 30/07/2016

\begin{abstract}
In Mansfield Park, Jane Austen has exhibited the English identity lies on property earned by the slave trade in Caribbean Islands. If we go deep inside of the history of Britain we could able to see their awareness and concern over a national identity, and consider American colonies a poor reflection on Britain. The traits of British colonization always stretched their dominating wings soar above in the sky of ruling. The tyrannical rule on the Caribbean Islands and other places, where they have set the subjugation upon the destitute subjects. Such as West Indies, Jamaica, Haiti, Indian subcontinent and many more countries which they consider inferior in front of them. This was the ideology of English people and their smug of English identity. In the first part of my research paper, I am suppose to depict that, how the English superiority discern its voice through the narrative of the $19^{\text {th }}$ century English novels. The great example of English superiority proved by the reading of Mansfield Park, and this novel will also explore the deepest meaning of coveted Englishness. Jane Austen's Mansfield Park, which has written based on English identity earned by slave trade and also the English people who are very much obsessed with property, money, status, elite class attitudes and heedless towards their subordinate people. On the other hands, Kazi Nazrul Islam upholds the position of anti colonial writer. He was very much against the British rule and their despotic rulers. Therefore, Kazi Nazrul Islam has established the notion of anti British ideology and activities through his writings and showed the world about his rebellious nature.
\end{abstract}

Keywords: Mansfield Park, British colonialism, Caribbean Islands, Anti-colonialism, Rebellion

\section{Introduction}

This thesis will explore the concept of British's colonial enterprise throughout the English literature of $19^{\text {th }}$ century. While on the other hands, it will focus on the counterpoint of colonial attitudes through the Bengali literature of $19^{\text {th }}$ century. First of all I would like to vignette the British ruler's anarchy inside of the English literature. The British Raj has generated the tainted demarcation by their establishment of empire state. This was the blackest and cruellest part of their former history of ruling. British government didn't comprehend their injustice upon the people of the Caribbean Islands who has lost their right to live properly. The inhabitants of the Caribbean Islands and the other subsequent British premises has deprived to lead their life and forfeited to ask for their basic rights. Hence, the English people's heedless and reckless attitudes towards their subjects made the novels of $19^{\text {th }}$ century more authentic about British imperialism. The readers of $19^{\text {th }}$ century or even now, the attributes of Englishness has always showed its superlative nature. Thus Jane Austen's Mansfield Park got the best example to me to analyse the British Raj's pride and as well as the English people's conduct upon their subordinate people. In Mansfield Park, it is utterly vivid that, slavery and the greed to grab the empire state becomes the prevailing thing. And they have maintained that traits to present them as an English entity. Money, land ownership, property seeking, elite class attitudes, all these things are the elements for the Englishness. Whereas the English people are tend to accelerate their superiority and as a result the British rule got the elevation of their ultimate position above all. According to Edward Said, English novels has marked its superiority because of their imperial conquest, the history of their ruling power and dominating conduct towards their subordinate subjects. He said, English novels has dominated in both the terrain of British and its colonies in the $19^{\text {th }}$ century. As Said, notes,

" never in the novel, in that world beyond seen except as subordinate and dominated, the English presence viewed as regulative and normative."

I am completely agree with what Said mentioned in his theory to understand the Englishness and make the outline of their prominent condition through the higher class and the exaggerated attributes. I must not examine the traits of Englishness but also their inability to accept the truth of earning their property through the slave trade. Hence, Jane Austen's perennial work Mansfield park showed how the colonialism prevail on the subordinate people. In Mansfield park, the stability, order and harmony of the Bertram estate in England are set off against the tempests tossed seas Sir 
Thomas Bertram navigates on his journey to Antigua where he owns substantial property. In Austen's time, an English reader would have had no difficulty grasping the fact that property in England such as Mansfield park was maintained by the labour of the natives of a plantation in the Antigua. Historically they would have been Britain at the center of the creole of influence, power and authority. Antigua would have been seen as the insignificant other and therefore marginal significance. Fanny who is the only character in the novel who asks a question about the slave trade. She gets no answer and Austen leaves it at that. She is disturbed yet timid and lacks the energy urgency to pursue that very important question. Fanny's question creates a pause, a momentary silence in the conversation but it does not disturb the harmony of the domestic circle of which she is a part when her cousin, Edmund points out to Fanny that is too silent in the evening circle", she asserts, referring to Sir Thomas Bertram,

"But I do not talk to him more than I used. I am sure I do. Did not you hear me ask him about the slave trade last night",(Austen, 198)

She goes on to say how she had longed to ask her uncle more question, but had been "such a dead silence" (Austen, 198)

Following her question about the slave trade. Sir Thomas's inability or unwillingness to answer Fanny's question provides an ironic contrast to his general interest in talking at great length about the west indies. It is the ownership of progeny in the West indies that makes possible the domestic comforts and tranquillity of the family gathered around Sir Thomas, listening to his stories about far away lands. As Fanny tells Edmund

"The evenings do not appear long to me. I love to hear my uncle talk of the West Indies. I could listen him for an hour" (Austen, 197)

She also observes of her uncle that, "the repose of his own family circle is all he wants" (Austen, 196)

Questions about colonization and slave trade Surely would disturb such repose. Austen thus leaves us with the comic awareness that though Fanny can see more, she does not go beyond a certain point instead she accepts the silence and do not force it to have meaning if she did, she would have to go against her habitually timid nature to challenge the unpleasant truth implied by the silence. A rebellious, outspoken Fanny would have to be a character in a very different novel. If Fanny were to question the silence, she would also question the foundations of Mansfield park. As a rebel, she would reject any participation in a social order and domestic stability based on injustice, oppression and the harsh truths of Antiguan property taken over in the name of civilization, patriotism, nationalism and glorious glories of the empire. It is a part of Austen's ironic design that Fanny, who stands at the moral center of the novel, should ask the question about slavery even though the pertinent question is left unanswered, hanging, incomplete. Austen thus teases the reader with a contradiction and choses to leave it unresolved simply because she can't resolve it. Edward Said sees Austen's reference to the slave trade as being morally neutral. Austen writes at a historical and cultural moment when as Said reminds us there is no language for the continuation of such a conversation. But she does disturb the surface in her characteristics vein, then quickly restores order and harmony. Finally as Austen proceeds to wrap up the novel's happy ending, Fanny marries Edmund, Sir Thomas recognize his faults, the stable home of Mansfield park is stronger than ever in its values occupants, but the spreading seas of influence and empire building lie outside the boundaries of her novel which emphasise the strong colonial attitudes through her text Mansfield park.

On the other hands, to the contrast of colonialism, now I would like to exhibit the counterpoint of colonialism which we call anti colonialism. In my above writing I have showed about English novel's superiority thus its concern towards colonialism. In $19^{\text {th }}$ century Bengali literature we have discern some great authors who fought against British imperialism through their writings. Kazi Nazrul Islam and Rabindranath are one of them. As a perennial author Kazi Nazrul Islam upholds the title of anti colonist rebel poet in Bangla literature. Being a Muslim musician, poet and novelist, he used his poetry to inspire Indians to rebel against British colonialism. He had several pieces of literature banned by the British government in an attempt to supress the rebellious movements. Bidrohi is one of his famous anti British poetry which immediately placed him in the public eye. In a time of rebellion and political unrest, Nazrul's poetry played a crucial role in uniting the oppressed and providing them with an intense sense of nationalism. He joined Swadeshi ( self rule) and boycotts British goods. He also composed many songs got participant to sing as the marched Nazrul fought, foreign rule, communalism, imperialism, colonialism, fundamentalism and exploitation. British government prescribed his books and put him behind bars. Through his written Rajbandir Jibanbondi ( Prisoner's Deposition) and his forty days hunger strike, Nazrul protested against the harassment. His writings were full of revolutionary messages that stirred up the spirit of freedom amongnest the grass roots level foiling masses. This made the British government cautious about Nazrul. Ultimately my purpose in writing this paper has two different sides for $19^{\text {th }}$ century's English literature, which is to depict the British government and English people's dominating, superlative nature and firmly established meaning of English traits and habituation. The proper and perfect narrative is Jane Austen's Mansfield park, which can eventually showed the superiority of imperialism, colonialism. In contrast with the colonialism, Kazi Nazrul Islam from Bengali literature encapsulate the anti colonist zeal of $19^{\text {th }}$ century.

\section{Theory of Colonialism}

The term colonialism derived from the superior traits over the inferior inhabitants. Colonialism is the notion of acquiring power from one powerful territory to the another territory. As we as colonialism denotes the atrocity, expansion and the exploitation of colony. The period of European colony was the era from $16^{\text {th }}$ century to the mid- $20^{\text {th }}$ century. In this time the European superlative realm established and spread their powers in Africa and Asia. Jürgen 
Osterhammel gave his theory about colonialism. Jürgen osterhammel's colonialism: A Theoretical Overview, Roger Tignor says,

"For Osterhammel, the essence of colonialism is the existence of colonies, which are by definition governed differently from other territories such as protectorates or informal spheres of influence".

Osterhammel asks in the book and remarks, how can colonialism be defined independently from colony? He came to the settlement of his curiosity and delivers a three sentence definition:

"Colonialism is a relationship between an indigenous (for forcibly imported) majority and a minority of foreign affecting the lives of the colonized people are made and implemented by the colonial rulers in pursuit of interest that are often defined in a distant metropolis. Rejecting cultural compromises with the colonized population, the colonizers are convinced of their own superiority and their ordained mandate to rule".

As a whole, it is to be noted that, colonialism is the mighty force to rule their subsequent colonies. They consider the colonized people as a barbaric, savage, peasants, ignorant, uncivilized. They also feel that, the colonized inhabitant's way of leading life is anomaly. Hence the superior colonizers think that they need to clean and polish the standards of the colonized nations. Their pride is certain to notice because of the ruling conduct towards to inferior subordinates. The colonizers are totally indifferent and consider the colonized people as the beggar of their British wisdom, they also feels the those inferior subjugated people got the dire needs of expertise from the colonizers which is salient.

As a result the white Europeans feel the wanderlust into the so called underdeveloped regions such as Africa and Asia. The white rulers started to imprison the inferior natives to inflict the European cultures, languages and other stuffs. In the mean time they plundered the wealth of natives and set up their supremacy above all.

\section{Theory of Anti-Colonialism/Imperialism}

Anti-colonialism/ imperialism is the term to roar the voice downtrodden people. Its the national movements and show the patriotism to stand against the despotic Colonizers. This phrase started after the second world war and the onset of the cold war as political movements in colonies of European powers. The first Anti-imperialist groups who opposed the United States and this was thought as social imperialism. Anti-imperialism originated in Europe in the late $19^{\text {th }}$ and early $20^{\text {th }}$ centuries. In the mid- $20^{\text {th }}$ century and later the variety of national liberation movements occurred. These movements were the basic foundation in the decolonized process of the 1950s and 1960s. In this time limit most European colonies in Asia and Africa achieving their independence.

\section{Mansfield Park as the Epitome of Imperial, weaves of Influence and Authority}

Jane Austen's Mansfield Park has been showed that, how colonialism is superior in front of other issues in the context of $19^{\text {th }}$ century literature. A minute reading of the novel demonstrates how colonial power can be articulated within the literary mainstream. The aim for choosing this novel is to examine the colonialism and its impact which has been affected the life of colonial others. The English blood smug with utmost triumph over everyone around them and grab the power of imperialism. The novel Mansfield Park sets the picture of imperial activities which has been the central topic. This novel is the true example of English traits, wealth and property. Sir Thomas Bertram estate in England are set off against the tempest tossed seas. He navigates on his journey to Antigua where he owns substantial property. In the time of Austen, the English readers had no hardship for tracing the fact of the English property such as Mansfield Park, was maintained of a plantation in the colony of Antigua. Historically, they would have been seen Britain at the center of the circle of influence, power and authority. Antigua would have been seen as the insignificant other and therefore of marginal significance. Gayatri Spivak pointed out about imperialism and its influence of Englishness on readers. She said in her essay, "Three women's texts and a critique of imperialism" that,

"It should not be possible to read nineteenth century British literature without remembering that imperialism understood as England's social mission, was a crucial part of the cultural representation of England to the English. The role of literature in the production of cultural representation should not be ignored" (Spivak, 798)

Here i strongly assert that, Spivak's realization about imperialism exhibited that the inhabitants of Antigua even would have had no problem in reading Jane Austen's Mansfield Park. Austen, in a better sense makes fine moral distinction in her fictional realm. But when it comes for the criticism, we could see main criticism. The twentieth century post colonial readers and critics from Antigua, England or any other part of the world, who has traced myriad contradictions and fragmentation in Austen's aesthetic presentation which were absent by the early colonial or even post colonial reader.

The basic shift in attributes is showed in Edward Said's observation of Mansfield Park. Said goes back to the fictional boundaries of Mansfield Park to include the historical dimension to know the West Indian colony that support of it. He argues: Sir Thomas's Antigua readily acquires a slightly greater density than the discreet, reticent appearances it makes in the pages of Mansfield Park. Said further observes that through a minute reading of Mansfield Park

"we can sense how ideas about dependent races and territories were held both foreign office executives, colonial bureaucrats, and military strategists and by intelligent novel reader educating themselves in the fine points of moral evaluation, literary balance, and stylistic finish" (Said, 95)

Here in Mansfield Park its odd to know about Austen's writing about the cruelty of slavery, he goes on to point out that Fanny's question about the slave trade is met with silence 
"as to suggest that one world could not be connected with the other since there simply is no common language for both" (Said, 96)

He finished by saying,

"In time there would no longer be a dead silence when slavery was spoken of and the subject became central to a new understanding of what Europe was" (Said, 96)

That time has arrived now. We have to discuss about slavery, property, the British empire, and Antiguan and British readers of Austen's Mansfield Park. I would dispute that if Jane Austen were writing Mansfield Park today, she could not have avoided making the ironic connections between Antigua and Mansfield Park of which she did in 1814.

A novelist has an own instinct to portray the traits and aims of her art. Austen as well knew what she was writing when she wrote and published Mansfield Park. Fanny is the only character in the novel who asks a question about the slave trade. She gets no answer, and Austen had no concern about that. She perhaps was messed and heedless to provide that certain question about slavery. Fanny's question creates a gap, a momentary silence in the conversation but it does not disrupt the unity of the domestic circle of which is a part. When her cousin Edmund points out to Fanny that she is too quite and calm in the evening circle, she asserts, referring to sir Thomas Bertram, "But I do talk to him more than $\mathrm{i}$ used, I am sure i do. Did not you hear me ask him about the slave trade last night?" (Austen, 198)

She goes on to say how she had yarned to ask her uncle more question, but hesitated because there had been "such a dead silence" (Austen, 198).

Following her question about the slave trade. Sir Thomas's reluctance to answer Fanny's question provides an ironic contrast to his general interest in talking at great length about the West Indies. The ownership of Mansfield's property has earned through the struggle of West Indian's slaves. Hence, the domestic comfort and tranquillity of the family came. Fanny tells Edmund,

"The evenings do not appear long to me. I love to hear my uncle talk of the West Indies. I could listen to him for an hour together" (Austen, 197)

She denotes about her uncle that

"the repose of his own family circle is all he wants" ( Austen, 196)

So question about colonization and the slave trade would surely impaired such repose. It is the unimportant awareness that though Fanny can see more she does not go beyond a certain point. Instead, she accept the silence and does not force to have meaning. If she did, she would have to go against her habitually timid nature to challenge the unpleasant truth implied by the silence. A rebellious frankly talking Fanny would have to be a character in a different novel. If Fanny were to question the silence, she would also question the foundation of Mansfield Park novel. As she is a insurgent minded character, she would obviously disown any kind of injustice, oppression and cruel truth of Antiguan property taken over in the name of civilization, patriotism, nationalism and the perennial success of British empire. That is why Austen avoided to inquiry about the slave trade in Antigua. Austen's purpose was to keep the British superiority alive in front of her readers. As a rebel and extraordinary character, Fanny would have ask the question about slavery even though the pertinent question is left unanswered, hanging, incomplete. It seems Austen teases the reader with a contradiction and decides to leave the question unanswered. Simply she does prove the eliteness of English people and property. Austen actually disturbs the surface in her characterization which is void, then quickly picks the order and unity. Fanny finally married Edmund, Sir Thomas Bertram recognizes his faults, the stable home of Mansfield Park is stronger than ever in its values and occupants, but the mystery of Mansfield Park's property gaining Process left outside the demarcation line of her novel.

After all $\mathrm{i}$ would strongly assert that Austen consider the enlightenment of colonialism and take a close look at the individual in a social and political context. She generates within an accepted paradigm of patriotism, nationalism. It would be irrevocable to break away from this accepted social and political order without demolishing the very roots of British cultural identity. Austen actually underlines ideal moral values, even ideal feminist values without answering all the contradictory question only to protect the imperialism. To sum up, I feel that, there might be the inherent contradiction in the fact that though Fanny lives at a higher level of consciousness, she also echoes the embroiled British empire as she celebrates her brother's fortunes and adventures at sea.

\section{Kazi Nazrul Islam as a poet of Rebellion and the True Representer of Anti Colonialism of $19^{\text {th }}$ Century Bengali Literature}

Kazi Nazrul Islam was a poet of indescribable wrath against oppression, injustice under he British subjugation. He was a poet of insurgency, the flag bearer of love towards humanity, the absolute fighter to establish the parity among all religion. Kazi Nazrul Islam was the man, who was considered as a shining star in Bengali literature. His noble works were endorsed its igneous emblem in the history of enlightening humans.

All of Kazi Nazrul Islam's writings are taken as an unprecedented work. His genuine and honest activities for equal human rights and to combat against British rule made him the most prominent national poet of Bangladesh. His only goal was to set the right less people stand strong in their life and also serve them the proper rights which they have forfeited or lost. Those right less or power less people are the labourers, workers, farmers, peasants, outlawed persons, deprived women in society. Nazrul's writings thus inspired the freedom of India in 1947. 
In my this part of anti colonialism, I would like to present how and why this ordinary man Kazi Nazrul Islam became the extra ordinary figure among his nation and as well as in front of the whole world of literature. Nazrul Islam was actually born in a Bengali Muslim family. From his childhood he observed and passed many hurdles and faced the life's intense agony and sufferings. Those bitter experiences of hardship made Kazi Nazrul Islam more pure and vehement. Gradually from his early stage of life, he started to write different types of fierce poems against injustice and atrocity. His poems, songs, short stories, essays were contained the consolidate message about humanity and the contemplation about the independence of his nation from the grips of British Raj. Therefore, he inspired the Indians to rebel against British colonialism and thus he got the title of Bidrohi (The Rebel).

When he was becoming the prevailing voice in society, most of his literary works were banned by the British colonial government in an attempt to suppress the rebellious movements. But he never stopped himself from writing. Instead of it, he started to elevate the whole nation through his writing skills. As a scintillating person he has won many hearts filled with respect and love for him. During the great liberation war and all democratic movements, Kazi Nazrul Islam was the only name of inspiration and constant healing supplier towards the fighter against the tyranny, and abjectifying human nature.

Kazi Nazrul Islam wrote more than 2,000 songs which are known as Nazrul Geeti or Nazrul Sangit. He himself liked to tune and composed all of his songs. Nazrul's one of the master piece is Bidrohi (The Rebel). This poem made him perennial in the domain of rebellious poems. The style of this poem catched the eye of millions spectaculars in Bengali literature, as well as the world literature. From that time to till now Nazrul's poem Bidrohi has captivated by the readers.

Following Kazi Nazrul Islam's first rebellious poem Bidrohi, he joined the Swadeshi (self-rule) movement led by Subhas Chandra Bose and many other anti colonial movements and also he did boycotts all the British goods. With all his fierce movements, Nazrul has composed many songs for participants to sing as they marched on the road of gaining justice, humanity, equality for the powerless, needy and right less people in the society. His struggle didn't stop with hardship only but also send him to jail by the British government. Nazrul's own magazine Dhumketu (The Comet) which featured anti colonial poems that manifested the true tyrannical rule of British Raj. Fight against oppression and the urge for independence was the main notion of Kazi Nazrul Islam, and as a result his rebellious traits and growing fame had to pay badly, because the British raided the magazine Dhumketu and arrested Nazrul and jailed him until late 1923.

After staying in jail, Nazrul participated in the publication of many other magazines, multiple rebellious songs, poems and political essays that argued against the partition of British India into two different states (Islamic Pakistan and Hindu India). To stand still with Nazrul's this very ideology against British government, he showed us and exhibited us his voice against oppression through his poetry. For examples, Bidrohi (The Rebel) from Agnibina. Birangona (The Whore), Chor- Dakat (Thieves), Nari (women), kuli-Majur (Labourers and workers) from Samyabadi, Kandari Hushiar (Helmsman Beware), Chashar Gaan (The song of the Peasants) from Nirjhar, Otho re Chashi (wake up o Peasant) from Natun-Chand and Krisoker Gaan (The song of the peasant). All of these poems showed the protest against injustice, oppression by the British rulers on the general people of Bengal region. Among all of his poems Bidrohi considered as his best known poems which has delivered the messages about fight for independence from the paws of falsehood, hypocrisy, inequality, subjugation under the British's rule. In another sense this poem is the seed to fight against the Colonialism and made a solemn pledge to eradicate their despotic nature of ruling. Here are some few lines from the famous poem Bidrohi (The Rebel)

I am the unutterable grief,

I am the trembling first touch of the virgin,

I am the throbbing ten,

I am the wild fire of the woods,

I am Hell's mad terrific sea of wrath!

I ride on the wings of lightning with joy and profundity,

I scatter misery and fear all around,

I bring earth-quakes on this world! "(8th stanza)"

Weary of struggles, I, the great rebel,

Shall rest in quiet only when I find

The sky and the air free of the piteous groans of the oppressed.

Only when the battle fields are cleared of jingling bloody sabres

Shall I, weary of struggles, rest in quiet,

I am the rebel eternal,

I raise my head beyond this world and,

High, ever erect and alone! "(Last stanza)"

Other poems of Nazrul are slightly different than Bidrohi but united in a common ideology about the working class people, thieves and robbers, prostitutes and women. Thieves and prostitutes are the people who has been prohibited from the society and a mandatory thing to disown them from the society as well. They are considered as an outlawed people. While the labourers and workers has bought a life of struggle and pain. Nazrul's poems claimed the involvement of the rejection of discriminatory social and human statues. Instead of injustice and inequality, Nazrul 
offered justice, equality, tranquillity to transcend the condition of oppression and marginalised condition of the powerless people.

Above discussion about Kazi Nazrul Islam's writings proclaimed his absolute honesty and motive to end the inequality and exploitation from the mighty perpetrators. All of his poems, songs, anthologies, essays has encapsulated the enormous struggle of subaltern class and also the way of coming out from the suppressed life against the British colonialism.

\section{Conclusion}

To sum up, it is clearly noted that, the colonizers from the west are always posses dominating attitudes which we can see through Jane Austen's Mansfield Park. The main messages of this Research paper will unveiled the superiority of English texts of $19^{\text {th }}$ century as well as well as it will encounter with the domain of anti colonialism. In the first part of my Research paper I have tried to figure out the superiority and desirability of Jane Austen's Mansfield park. The imperial activities and greed to become the great ones made the British government and the English inhabitants the real unjust, unkind, senseless and selfish existence on earth. They have only known by their superlative pride, pampered elite class, land ownership nature and handsome amount of pounds through the heartfelt struggles of slave trade. In the novel Mansfield Park, Fanny was the only character who has asked about slave trade to Sir Thomas Bertram. But he didn't answer and later on Fanny also kept mum about this important issue. She became busy in her domestic affairs which is the basic traits of English people. Fanny was presented like them. Therefore this novel seems to have the resemblance of another English novel like Jane Eyre by Charlotte Bronte. Following the so called English attributes, Austen tried to keep the English superiority alive through her novel Mansfield Park. On the other hands, easterners are certainly lies under the westerners as a submissive slave. Where there has raised the question of anti colonialism. Kazi Nazrul Islam from Bangladesh who was very much against the British rule. He wrote many rebellious poems, songs, anthologies to prove her patriotism and showed his hatred towards British colonialism. Kazi Nazrul's first poem “ The Rebel" made him famous all over the country as well as the outside of his country's periphery. The elements of firing words are so deeply packed in this poem. Thus Nazrul depicted his real talent and after that, he wrote many more like this poem Bidrohi ( The Rebel). Even in jail he didn't stop writing. Hence, All of his writings has carried the true sense of nationalism and patriotism, that is why he is known as anti colonial writer in every possible way.

\section{References}

Austen, J. (1934). Mansfield Park. The Novels of Jane Austen. Vol. III, $3^{\text {rd }}$ ed. Oxford: Oxford University press.

Abdul, H. (1974). The Fiery Lyre of Nazrul Islam, (Bangla Academy; Dhaka).

Nurul Huda, M. (2001). Nazrul's Aesthetics and Other Aspects. Bangladesh: Nazrul Institute. P.124.

Osterhammel, J. (2005). Colonialism: Theoretical Overview, Princeton, NJ: M. Wiener.

Perry, R. (1994). Jane Austen and Empire: A thinking Woman's Guide to British Imperialism. Persuasions 16,95-105.

Said, E. (1991). Culture and Imperialism. New York: Knof.

Spivak, G. (1991). Three Woman's Texts and a critique of Imperialism" in Feminism: An Anthology of Literary Theory and Criticism Eds. Robyn Warhol and Diane Herndl. New Brunswick, NJ: Rutgers University press. 